\title{
Optimization of a protocol for direct organogenesis of red clover (Trifolium pratense L.) meristems for breeding purposes
}

\author{
JUAN C. CARRILLO, VERÓNICA A. OJEDA, HUGO A. CAMPOS-DE QUIROZ ${ }^{(*)}$ and \\ FERNANDO M. ORTEGA
}

Departamento de Producción Vegetal, Centro Regional de Investigación Carillanca, Instituto de Investigaciones Agropecuarias, Temuco, CHILE.

(*) Current address: Semillas Pioneer Chile Ltda. Coyancura 2241, piso 3, Providencia, Santiago, CHILE.

\begin{abstract}
A series of experiments were carried out in order to optimize a protocol for the direct organogenesis of Chilean red clover germplasm. A range of cultivars were used to analyze the effect of explant source (crown or stem meristems of vegetative plants), culture media and plant growth regulators. Our findings showed that stem meristems were easier to obtain, presented lower levels of contamination and a better development than crown meristems. The L2 medium showed better results than B5 and MS media for the cultivars and experimental lines studied. L2 medium supplemented with $0.003 \mathrm{mg} / 1$ of 4-amino-3,5,6-trichloropicolinic acid and $1.0 \mathrm{mg} / \mathrm{l}$ of 6-benzylaminopurine gave consistently better results and will be applied in our breeding program to propagate, maintain and eliminate viruses from elite red clover clones.
\end{abstract}

Key terms: In vitro culture, meristem culture, red clover, Trifolium pratense L.

\section{INTRODUCTION}

Red clover is a valuable forage legume in temperate regions of the world. Grown alone or mixed with grasses, red clover produces high yields and good quality forage in a wide range of soil types, $\mathrm{pH}$, environmental and management conditions (Bowley et al., 1984; Smith et al., 1985; Taylor and Quesenberry, 1996). This legume is especially relevant to Chile because of the extensive area covered (more than $20 \%$ of the sown pastures) and seed exports, amounting to 770-1000 t/year (over $70 \%$ of the total forage seed exports of Chile) (Ortega et al., 1998). Nevertheless, as in most of the world, its use by farmers is restricted by the lack of persistence related to high mortality of plants, determining a productive life of two to three years (Rhodes and Ortega, 1996;
Rhodes and Ortega, 1997; Ortega et al., 1998; Ortega et al., 2003). This also limits the genetic progress of breeding programs due to the difficulty in maintaining selected genotypes under field or greenhouse conditions and moreover, because of the allogamous nature of the species that makes it impossible to maintain elite clones by seed (Taylor and Quesenberry, 1996).

Considering these limitations, protocols for in vitro tissue culture of meristems adapted to specific germplasm have been developed to propagate, eliminate viruses, and maintain red clover clones (Phillips and Collins, 1979; Cheyne and Dale, 1980; Campbell and Tomes, 1984; Dale and Cheyne, 1993). Phillips and Collins (1979) developed the L2 medium and obtained good results when culturing meristems of clones of the cultivar Kenstar in this medium supplemented with the plant 
growth regulators (PGR) 4-amino-3,5,6trichloropicolinic acid (PIC) and 6benzylaminopurine (BAP) with subsequent transfer to the rooting RL medium. Cheyne and Dale (1980) tested different media and PGR and obtained good results with two cultivars of red clover cultured either in the Blaydes (Blaydes, 1966) or B5 media (Gamborg et al., 1976) with the PGR indole-3-acetic acid (IAA, $0.2 \mathrm{mg} / \mathrm{l}$ ) and $\mathrm{N}^{6}-\left(\Delta^{2}\right.$-isopentenyl) adenine (2iP, $\left.0.2 \mathrm{mg} / \mathrm{l}\right)$. Dale and Cheyne (1993) used a similar protocol to eliminate clover diseases of seven cultivars and obtained good results using the B5 medium with identical PGR levels. On the other hand, Campbell and Tomes (1984) also achieved good results with the B5 medium but using the PGR BAP $(2.0 \mathrm{~g} / 1)$. It is evident that the requirements for successful meristem culture vary within species, especially in an outcrossing species like red clover.

This paper is part of a project that aims to develop biotechnological tools to enhance our red clover breeding program. Other results related to molecular markers have been published elsewhere (Camposde Quiroz and Ortega, 2001; Ulloa et al, 2003), and a general review of applications to plant genomics was also published recently (Campos-de Quiroz, 2002). The objective of this research was to optimize protocols for the direct organogenesis of meristems adapted to Chilean red clover germplasm. A series of experiments were carried out to establish the appropriate explant source (crown or stem meristem), culture media (MS, Murashige and Skoog, 1962; B5; and L2) and PGR combination.

\section{MATERIALS AND METHODS}

Details of the five experiments, considering a range of cultivars, explant source, culture media and combination of PGR are shown in Table I.

TABLE I

Layout of the experiments carried out to optimize a protocol for direct organogenesis of red clover meristems

\begin{tabular}{|c|c|c|c|}
\hline Experiment & $\begin{array}{l}\text { Explant } \\
\text { source }\end{array}$ & $\begin{array}{l}\text { Cultivars and } \\
\text { experimental lines }\end{array}$ & $\begin{array}{l}\text { Media and plant } \\
\text { growth regulators }\end{array}$ \\
\hline I and II & $\begin{array}{l}\text { Stem and } \\
\text { crown } \\
\text { meristems }\end{array}$ & $\begin{array}{l}\text { Quiñequeli-INIA, Redqueli-INIA, } \\
\text { Syn IV, Syn VI, Altaswede, } \\
\text { NEWRC }\end{array}$ & $\begin{array}{l}\text { B5 }(0.2 \mathrm{mg} / 1 \mathrm{NAA}) \\
\text { B5 }(0.2 \mathrm{mg} / 1 \mathrm{IAA}+0.2 \mathrm{mg} / 12 \mathrm{iP}) \\
\text { at } 30 \text { days transferred to the same medium } \\
\mathrm{L} 2(0.004 \mathrm{mg} / \mathrm{PIC}+1 \mathrm{mg} / \mathrm{BAP}) \\
\text { at } 30 \text { days transferred to } \mathrm{RL}(0.2 \mathrm{mg} / \mathrm{IAA})\end{array}$ \\
\hline III & $\begin{array}{l}\text { Stem } \\
\text { meristems }\end{array}$ & $\begin{array}{l}\text { Quiñequeli-INIA, Redqueli-INIA, } \\
\text { Altaswede, NEWRC }\end{array}$ & $\begin{array}{l}\text { MS (plant growth regulator free); } \\
\text { at } 15 \text { days transferred to the same medium } \\
\mathrm{L} 2(0.004 \mathrm{mg} / \mathrm{PIC}+1 \mathrm{mg} / \mathrm{BAP}) ; \\
\text { at } 15 \text { days transferred to } \mathrm{RL}(0.2 \mathrm{mg} / \mathrm{l} \mathrm{IAA})\end{array}$ \\
\hline IV & $\begin{array}{l}\text { Stem } \\
\text { meristems }\end{array}$ & $\begin{array}{l}\text { Quiñequeli-INIA, Redqueli-INIA, } \\
\text { Altaswede, NEWRC }\end{array}$ & $\begin{array}{l}\text { MS }(0.004 \mathrm{mg} / 1 \mathrm{PIC}+1 \mathrm{mg} / 1 \mathrm{BAP}) ; \\
\text { at } 15 \text { days transferred to } \mathrm{MS}(0.2 \mathrm{mg} / \mathrm{l} \mathrm{IAA}) \\
\mathrm{L} 2(0.004 \mathrm{mg} / \mathrm{PIC}+1 \mathrm{mg} / \mathrm{BAP}) ; \\
\text { at } 15 \text { days transferred to } \mathrm{RL}(0.2 \mathrm{mg} / 1 \mathrm{IAA})\end{array}$ \\
\hline V & $\begin{array}{l}\text { Stem } \\
\text { meristems }\end{array}$ & Quiñequeli-INIA, Redqueli-INIA & $\begin{array}{l}\text { L2 }[6 \text { combinations of } 3 \text { PIC levels } \\
(0.003 ; 0.004 ; 0.005 \mathrm{mg} / 1) \text { and } 2 \text { BAP } \\
\text { levels }(0.5 ; 1.0 \mathrm{mg} / 1)] ; \text { at } 15 \text { days } \\
\text { transferred to RL }(0.2 \mathrm{mg} / 1 \text { IAA })\end{array}$ \\
\hline
\end{tabular}




\section{Plant material}

The germplasm source varied according to the experiment and they included the Chilean cultivars and experimental lines Quiñequeli-INIA, Redqueli-INIA, Syn-IV and Syn-VI and the foreign germplasm Altaswede (Canada) and NEWRC (USA). NEWRC was selected by the University of Wisconsin for high regeneration capacity of petioles cultivated in B5 medium (Smith and Quesenberry, 1995).

\section{Culture procedures}

Vegetative plants were used in all the experiments. Crown or shoot tips measuring 1 to $2 \mathrm{~cm}$ in length that contained meristems were surface sterilized by immersion in $70 \%$ ethanol for $2 \mathrm{~min}$, followed by $7 \mathrm{~min}$ in $2 \%$ sodium hypochlorite with one drop of Tween 20 per $100 \mathrm{ml}$ and rinsed in sterile water three times. Meristems containing the meristematic dome and 1 to 2 foliar primordia ranging in diameter from 0.1 to $0.7 \mathrm{~mm}$ were excised with the help of a stereoscopic magnifier in a laminar flow cabinet. Meristems were grown in vitro in individual glass tubes of $40 \mathrm{cc}$ each, in a growth chamber at $25^{\circ} \mathrm{C}$ with $18 \mathrm{~h} / 6 \mathrm{~h}$ day/ night photoperiod and 2000 lux. After 60 days, regenerated plants with at least 2 trifoliate leaves and more than 2 main roots were transplanted to individual pots containing sterile soil, inoculated with a local strain (F-103) of Rhizobium leguminosarum biovar trifolii and kept in the same growth chamber for 1 week. At the end of this period, plants were transferred to a greenhouse.

\section{Measurements}

The following parameters were recorded at 15,30 , and 60 days of culture: number of shoots/meristems, shoot height $(\mathrm{mm})$ and rooting (number of main roots). The efficiency of the hardening process was evaluated by the number of clones surviving after 2 weeks of transferring potted plants to the greenhouse.

\section{Experimental design and statistical analysis}

The experiments were arranged in a completely randomized design with varying number of replicates depending on the experiment (6 in the experiment I and II, 15 in the experiments III and IV, 10 in the experiment V). Each replicate consisted of 1 meristem excised from 1 genotype, using the same genotypes for the different combinations of $\mathrm{PGR} /$ media of each experiment. Variables were analyzed by variance analysis and LSD mean separation using the Statistical Analysis Software release 6.12 (SAS Institute, Inc.1996).

\section{RESULTS}

Callus formation only occurred when meristems were cultured in B5 medium supplemented with NAA as the auxin source (experiments I and II). All the other combinations of media and PGR allowed normal growth of the meristems without forming calluses. In experiments I and II, there was no significant effect of cultivar on the evaluated parameters (Table II). Plantlets grown in L2 medium had a higher shoot height than in B5, both for stem and crown meristems. This was reflected at 60 days of culture when $45 \%$ of the meristems grown in L2 medium developed plantlets suitable for transplanting, compared to $30 \%$ from B5. Both stem and crown meristems developed plants with normal growth, although stem meristems had lower levels of contamination and a higher number of explants with shoots than crown meristems.

Stem meristems grown in the L2 medium with PGR developed a significantly higher number of shoots than in MS medium with no PGR at 60 days (Experiment III, Table III). There were no significant differences for rooting and shoot height. This was the only experiment that exhibited a significant effect of cultivar on the number of shoots and roots, with Redqueli-INIA showing the highest number of shoots and Altaswede the lowest rooting. The better performance of $\mathrm{L} 2$ medium resulted in $45 \%$ of the plantlets ready for transplant at 60 days, compared to $33 \%$ of MS. 


\section{TABLE II}

Height $(\mathrm{mm})$ of shoots developed from meristems grown on media B5 $(0.2 \mathrm{mg} / \mathrm{lAA}+0.2 \mathrm{mg} / \mathrm{l} 2 \mathrm{iP})$ and L2 $(0.004 \mathrm{mg} / \mathrm{PIC}+1.0 \mathrm{mg} / \mathrm{l} \mathrm{BAP})$ after 30 days of culture (Experiments I and II)

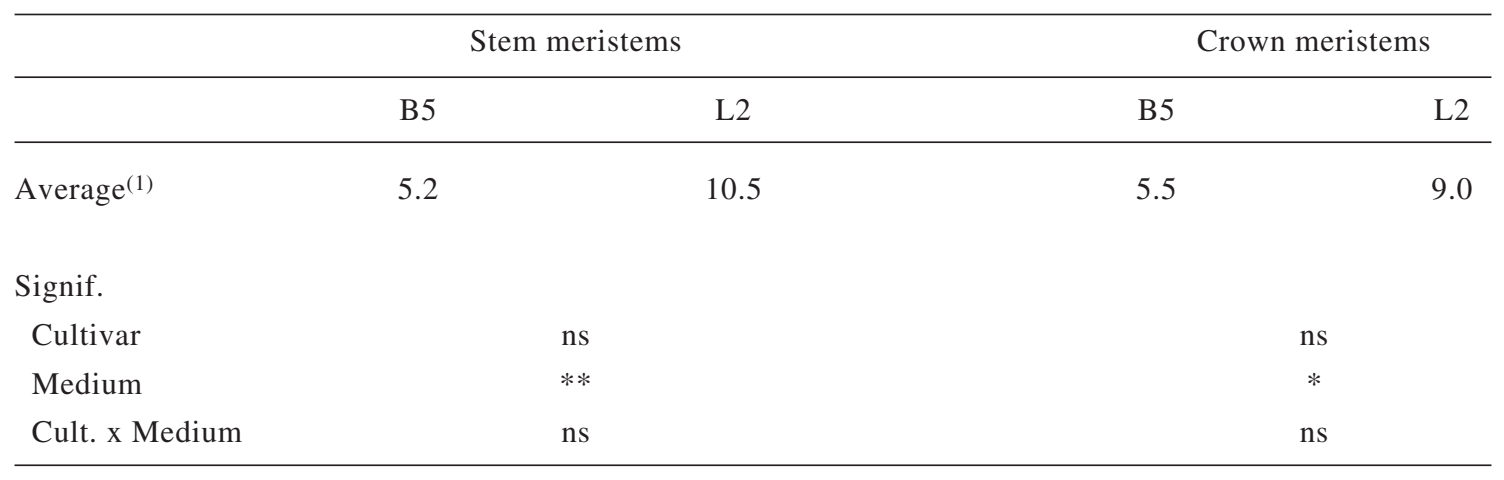

ns indicates non-significant differences $*$ and $* *$ significant differences

( $\mathrm{p} \leq 0.05$ and $\leq 0.01$, respectively).

(1) Average of 6 cultivars, 6 replicates per cultivar.

TABLE III

Comparison of media MS (plant growth regulators free) and L2 $(0.004 \mathrm{mg} / \mathrm{l} \mathrm{PIC}+1.0 \mathrm{mg} / \mathrm{l} \mathrm{BAP}$ for 15 days, $\mathrm{RL}+0.2 \mathrm{mg} / \mathrm{l}$ IAA afterward $)$ after 60 days of culture (Experiment III)

\begin{tabular}{lccc}
\hline $\begin{array}{l}\text { Cultivar } \\
\text { Shoots/meristem }\end{array}$ & $\begin{array}{c}\text { Number of } \\
\text { roots/meristem }\end{array}$ & $\begin{array}{c}\text { Number of } \\
(\mathrm{mm})\end{array}$ & Height \\
\hline Quiñequeli(1) & 4.0 & 2.6 & 2.6 \\
Redqueli & 4.9 & 2.8 & 2.9 \\
Altaswede & 3.5 & 1.1 & 1.9 \\
NewRC & 4.5 & 3.2 & 3.1 \\
Average MS & 3.3 & 2.3 & 2.3 \\
Average L2 & 5.2 & 2.5 & 3.0 \\
General average & 4.3 & 2.4 & 2.7 \\
& & & $\mathrm{~ns}$ \\
Signif. & $* *$ & $*$ & $\mathrm{~ns}$ \\
Cultivar & $* *$ & $\mathrm{~ns}$ & $\mathrm{~ns}$ \\
Medium & $\mathrm{ns}$ & $\mathrm{ns}$ & - \\
Cult. x Medium & & & - \\
LSD & 0.79 & 1.40 & - \\
Cultivar & 0.56 & & \\
Medium & & & \\
\hline
\end{tabular}

ns indicates non-significant differences $*$ and $* *$ significant differences

( $\mathrm{p} \leq 0.05$ and $\leq 0.01$, respectively).

LSD indicates Least Significant Differences $(\mathrm{P} \leq 0.05)$.

(1) 15 replicates per cultivar. 
When we compared the MS and L2 media with the same PGR (Experiment IV, Table IV), L2 was consistently superior to MS regarding number of shoots, rooting and shoot height at 60 days. Again, no effect of cultivar or interaction cultivar $\mathrm{x}$ medium was observed.

The former experiments demonstrated the superiority of L2 medium for direct organogenesis of meristems in the studied cultivars and experimental lines. When we compared the growth of meristems in L2 medium with three levels of PIC and two levels of BAP (Experiment V), the evaluation performed at 15, 30 and 60 days showed no significant effects of cultivar, combination of PGR, or the interaction of them. Nevertheless, the combination 0.003 $\mathrm{mg} / \mathrm{l}$ of PIC $+1.0 \mathrm{mg} / \mathrm{l}$ of BAP showed a consistent good performance for both Quiñequeli-INIA and Redqueli-INIA. On average, $60 \%$ of the plantlets were suitable for soil transplant after 60 days, while most of the remaining plantlets were suitable before 90 days.

\section{DISCUSSION}

Callus is undesirable for maintenance of elite clones because of the genetic instability associated with the undifferentiated growth of this structure. Callus formation only occurred when we cultured meristems in B5 medium supplemented with the growth regulator NAA. Cheyne and Dale (1980) also observed callus formation when they cultured meristems of the cultivar Norseman in B5 medium supplemented with NAA. However, they obtained a small percentage of direct organogenesis, whereas in our case all the meristems formed calluses. This can be explained since we used meristems measuring 0.1 to $0.7 \mathrm{~mm}$, while they excised shoot tips measuring 0.2 to $4.3 \mathrm{~mm}$. Larger meristems grow faster (Campbell and Tomes, 1984; Dale and Cheyne, 1993) and can presumably support enough growth before the stimulus that triggers callus formation is perceived by meristematic cells.

TABLE IV

Comparison of media MS and L2 with similar levels of plant growth regulators ( $0.004 \mathrm{mg} / \mathrm{l} \mathrm{PIC}+1.0 \mathrm{mg} / \mathrm{l}$ BAP for 15 days, $0.2 \mathrm{mg} / \mathrm{l}$ IAA afterwards $)$ after 60 days of culture (Experiment IV)

\begin{tabular}{|c|c|c|c|c|c|c|}
\hline & \multicolumn{2}{|c|}{$\begin{array}{c}\text { Number of } \\
\text { Shoots/meristem }\end{array}$} & \multicolumn{2}{|c|}{$\begin{array}{l}\text { Number of } \\
\text { roots/meristem }\end{array}$} & \multicolumn{2}{|c|}{$\begin{array}{l}\text { Height } \\
(\mathrm{mm})\end{array}$} \\
\hline & MS & L2 & MS & L2 & MS & L2 \\
\hline Average ${ }^{(1)}$ & 3.2 & 4.2 & 0.6 & 1.8 & 8.1 & 28.7 \\
\hline
\end{tabular}

Signif.

Cultivar

ns

Medium

Cult. x Medium

$$
*
$$

ns ns

**

ns ns

**

ns 
When we compared stem and crown meristems (experiments I and II), we observed normal growth of both explants. However, there was less contamination with stem meristems and better plantlet regeneration. Phillips and Collins (1979) and Campbell and Tomes (1984) compared meristems coming from crowns of vegetative plants and axillary meristems of stems of flowering plants. They found that stem meristems did not present normal growth, lacking the ability to branch, whereas crown meristems exhibited normal growth. The difference with our results can be explained because we always used vegetative plants, both for the crown meristems and stem meristems. The good performance of stem meristems is valuable for breeding programs since they are easier to obtain than crown meristems and excising them does not damage the plant. Therefore, these meristem donor plants can be used in subsequent breeding procedures or to produce more meristems for in vitro culture purposes over time.

The size of the explant is important since it has been demonstrated that larger meristems or shoot tips are easier and faster to grow, generating a higher number of plantlets, although they are less efficient in eliminating viruses and other pathogens (Campbell and Tomes, 1984; Dale and Cheyne, 1993). We used small meristems as our aim was to maintain elite clones and eliminate viruses from them. The results obtained in terms of number of plants transplanted and plantlet growth are encouraging in relation to other authors, particularly if the small size of meristems used is taken into account.

The better performance of L2 medium compared to B5 and MS supports the findings of Phillips and Collins (1979), who developed protocols especially adapted to red clover. In our set of experiments, we achieved plant regeneration with the three media tested, although L2 medium always presented a faster development and a higher frequency of plantlet regeneration.

From experiment III onward we transferred the meristems to a rooting medium with no PGR or $0.2 \mathrm{mg} / \mathrm{l}$ of IAA after 15 days of culture. Former protocols using B5 or MS media (Cheyne and Dale, 1980; Campbell and Tomes, 1984; Dale and Cheyne, 1993) maintained the level of PGR constant during the complete culture period, while Phillips and Collins (1979) kept the level of PGR constant until the plantlets where 2.0 to $2.5 \mathrm{~cm}$ tall. The good regeneration that we achieved even with an early transfer to a nil or low PGR medium is an advantage, as in vitro culture using PGR could induce somaclonal variation (Damiani et al, 1990; Munthali et al., 1996). Keeping somaclonal variation at a minimum is important if the aim is to preserve the genetic identity of elite germplasm.

Since experiment V did not display any significant differences when comparing combinations of different levels of PIC and BAP, it is suggested that the range of concentrations of PGR used was rather narrow. Phillips and Collins (1979) compared different levels of PIC ranging from 0.0 to $0.008 \mathrm{mg} / \mathrm{l}$ and BAP from 0.0 to $1.0 \mathrm{mg} / \mathrm{l}$; when they used PIC levels higher than $0.006 \mathrm{mg} / \mathrm{l}$ there was callus formation, independently of the BAP level. Their optimum concentration of PGR was 0.004 $\mathrm{mg} / \mathrm{l}$ of PIC and $1.0 \mathrm{mg} / \mathrm{l}$ of BAP.

Our optimized protocol is applicable regardless of the genotype, an important issue for our breeding program. This is an advantage compared with other protocols such as the one reported by Campbell and Tomes (1984), which had a significant genotypic effect for multiplication ability. The reported protocol enables the micropropagation of a wide range of red clover genotypes, maintaining the genetic variability of red clover breeding programs and also contributes to efficient storage and maintenance of a collection of breeding materials. Furthermore, it provides the platform required to establish robust methods of genetic transformation in red clover.

\section{ACKNOWLEDGMENTS}

The authors are thankful for funding from CONICYT (Comisión Nacional de Investigación Científica y Tecnológica), competitive grant FONDECYT 1981123, 
and also thank Dr. Richard Smith of the University of Wisconsin for supplying seed of NEWRC red clover.

\section{REFERENCES}

BLAYDES DF (1966) Interaction of kinetin and various inhibitors in the growth of soybean tissue. Physiol Plant 19: 748-753

BOWLEY SR, TAYLOR NL, DOUGHERTY CT (1984) Physiology and morphology of red clover. Adv Agron 37: $318-347$

CAMPBELL CT, TOMES DT (1984) Establishment and multiplication of red clover plants by in vitro shoot tip culture. Plant Cell Tiss Organ Cult 3: 49-57

CAMPOS-DE QUIROZ H, ORTEGA F (2001) Genetic variability among elite red clover (Trifolium pratense L.) parents as revealed by RAPD markers. Euphytica, 122: 61-67

CAMPOS-DE QUIROZ H (2002) Plant genomics: an overview. Biol Res 35: 385-399

CHEYNE VA, DALE PJ (1980) Shoot tip culture in forage legumes. Plant Sci Lett 19: 303-309

DALE PJ, CHEYNE VA (1993) The elimination of clover diseases by shoot tip culture. Ann Appl Biol 123: 1-8

DAMIANI F, PEZZOTTI M, ARCIONI S (1990) Somaclonal Variation in Lotus corniculatus L. in relation to plant breeding purposes. Euphytica 46: 35-41

GAMBORG L, MURASHIGE T, THORPE A, VASIL K (1976) Plant tissue culture media. In vitro 12:473-478

MUNTHALI M, NEWBURY H, FORD-LLOYD B (1996) The detection of somaclonal variants of beet using RAPD. Plant Cell Rep 15: 474-478

MURASHIGE T, SKOOG F (1962) A revised medium for rapid growth and bioassays with tobacco tissue cultures. Physiol Plant 15: 473-497
ORTEGA F, GALDAMES R, AGUILERA A, ROMERO O, RUIZ I, SOTO P, TORRES A, CAMPOS-DE QUIROZ $\mathrm{H}$ (1998) Advances in red clover breeding in Chile. In: GRAU C (ed) Proceedings of the fifteenth Trifolium conference. Madison, WI, USA: University of Wisconson Press. p: 16

ORTEGA KF, GALDAMES GR, AGUILERA PA, ROMERO YO, RUIZ NI, SOTO OP,

TORRES BA (2003) Redqueli-INIA, nuevo cultivar sintético de trébol rosado. Agric Tec (Chile) 63(2): 207-211

PHILLIPS GC, COLLINS GB (1979) Virus symptom-free plants of red clover using meristem culture. Crop Sci 19: $213-216$

RHODES I, ORTEGA F (1996) Progress in Forage Legume Breeding. In: YOUNIE D (ed) Legumes in sustainable farming systems. British Grassland Society occasional symposium \#30, Aberdeen, Scotland. pp: 62-71

RHODES I, ORTEGA F (1997) Plant breedingachievements and prospects, Forage Legumes. In: WEDDELL J (ed) Seeds of Progress. British Grassland Society occasional symposium \#31, Nottingham, England. pp: 15-27

SAS INSTITUTE INC (1996) SAS/STAT guide for personal computers, version $6,12^{\text {th }}$ ed., SAS Institute Inc., Cary, NC:

SMITH RR, QUESENBERRY KH (1995) Registration of NEWRC red clover germplasm. Crop Sci 35:295

SMITH RR, TAYLOR NL, BOWLEY SR (1985) Red clover. In: TAYLOR $\mathrm{N}$ (ed) Clover science and technology, Agronomy series 25, American Society of Agronomy, Madison, WI, USA. pp: 457-470

TAYLOR NL, QUESENBERRY KH (1996) Red clover science. The Netherlands: Kluwer Academic Publishers, Dordecht. p. 226

ULLOA O, ORTEGA F, CAMPOS H (2003) Analysis of genetic diversity in red clover (Trifolium pratense L.) breeding populations as revealed by RAPD genetic markers. Genome 46: 529-535 